\title{
A bibliometric review of oncolytic virus research as a novel approach for cancer therapy
}

\author{
Amir Sasan Mozaffari Nejad ${ }^{1}$ (D), Tehjeeb Noor ${ }^{2}$, Ziaul Haque Munim³ ${ }^{3}$, Mohammad Yousef Alikhani ${ }^{4^{*}}$ and \\ Amir Ghaemi ${ }^{*}$
}

\begin{abstract}
Background: In recent years, oncolytic viruses (OVs) have drawn attention as a novel therapy to various types of cancers, both in clinical and preclinical cancer studies all around the world. Consequently, researchers have been actively working on enhancing cancer therapy since the early twentieth century. This study presents a systematic review of the literature on OVs, discusses underlying research clusters and, presents future directions of OVs research.

Methods: A total of 1626 published articles related to OVs as cancer therapy were obtained from the Web of Science (WoS) database published between January 2000 and March 2020. Various aspects of OVs research, including the countries/territories, institutions, journals, authors, citations, research areas, and content analysis to find trending and emerging topics, were analysed using the bibliometrix package in the R-software.

Results: In terms of the number of publications, the USA based researchers were the most productive $(n=611)$ followed by Chinese $(n=197)$, and Canadian $(n=153)$ researchers. The Molecular Therapy journal ranked first both in terms of the number of publications $(n=133)$ and local citations $(n=1384)$. The most prominent institution was Mayo Clinic from the USA $(n=117)$ followed by the University of Ottawa from Canada $(n=72)$, and the University of Helsinki from Finland $(n=63)$. The most impactful author was Bell J.C with the highest number of articles $(n=67)$ and total local citations $(n=885)$. The most impactful article was published in the Cell journal. In addition, the latest OVs research mainly builds on four research clusters.

Conclusion: The domain of OVs research has increased at a rapid rate from 2000 to 2020. Based on the synthesis of reviewed studies, adenovirus, herpes simplex virus, reovirus, and Newcastle disease virus have shown potent anticancer activity. Developed countries such as the USA, Canada, the UK, and Finland were the most productive, hence, contributed most to this field. Further collaboration will help improve the clinical research translation of this therapy and bring benefits to cancer patients worldwide.
\end{abstract}

Keywords: Cancer, Oncolytic virus, Virotherapy, Bibliometric, Dynamic co-citation

*Correspondence: alikhani43@yahoo.com; alikhani@umsha.ac.ir; ghaem_ amir@yahoo.com; a_ghaemi@pasteur.ac.ir

${ }^{4}$ Department of Microbiology, Faculty of Medicine, Hamadan University of Medical Sciences, Hamadan, Iran

${ }^{5}$ Department of Influenza and Other Respiratory Viruses, Pasteur Institute of Iran, Tehran, Iran

Full list of author information is available at the end of the article

\section{Background}

Cancer is a dreadful disease and one of the leading causes of morbidity and mortality worldwide. According to the latest assessment on cancer's global burden of cancer by the International Agency for Research on Cancer (IARC) in September 2018, the number of cancer patients has risen by 18.1 million new cases, and 9.6 million deaths [1]. Some of the factors behind the growing cancer burden can be population growth and ageing, prevalent reasons linked to the socio-economic development, original author(s) and the source, provide a link to the Creative Commons licence, and indicate if changes were made. The images or other third party material in this article are included in the article's Creative Commons licence, unless indicated otherwise in a credit line to the material. If material is not included in the article's Creative Commons licence and your intended use is not permitted by statutory regulation or exceeds the permitted use, you will need to obtain permission directly from the copyright holder. To view a copy of this licence, visit http://creativecommons.org/licenses/by/4.0/. The Creative Commons Public Domain Dedication waiver (http://creativeco mmons.org/publicdomain/zero/1.0/) applies to the data made available in this article, unless otherwise stated in a credit line to the data. 
and improvement in medical diagnostic procedures. According to a recent study, among the continents, Asia accounted for almost fifty percent of new cases and more than half of the cancer death [2]. There are several therapeutic procedures for cancer treatment, including chemotherapy, radiotherapy, targeted therapy, surgery, stem cell transplant, hormone therapy, and precision medicine. The therapy protocol depends on the site and staging of cancer, patient profile, and availability, among other factors $[3,4]$. Most cancer treatment modules are reported to have adverse effects leading to unsatisfactory quality of life and death. Thus, research for new treatment options, limiting the adverse effects, improving life quality during and after treatment, and increasing the efficacy, is ongoing for several years [5]. Oncolytic virotherapy is one of the recent developments in the treatment of cancer.

Oncolytic viruses (OVs) are a novel treatment modality that uses natural or genetically modified (GM) viruses, which, upon infection, selectively replicate and kill neoplastic cells without any severe effects on normal cells. Generally, OVs fall into two categories. The first category includes viruses that normally replicate rather in cancer tissue and are non-pathogenic in humans, such as, autonomous parvoviruses, Seneca Valley virus (SVV), myxoma virus, Reovirus (respiratory enteric orphan), and Newcastle disease virus (NDV). The other type includes viruses that are genetically engineered and/or genetically manipulated, such as vaccinia virus, poliovirus, adenovirus, measles virus, vesicular stomatitis virus (VSV), herpes simplex virus (HSV), and Zika virus [6-9].

There are several studies on OVs and their applications. In the present study, we use the bibliometric analysis method to examine the growth of studies on OVs. We extract bibliography data from the Web of Science (WoS) database from 2000 to March 2020. This study maps the overall research domain on the application of OVs as cancer therapy and extracts future research directions to guide further development in the field.

\section{Review of bibliometric studies}

Bibliometric analysis refers to the study of bibliographic information on published articles. As bibliometric analysis relies on statistical methods, it has emerged as a useful tool to assess the scientific publications in terms of quality and credibility. One of the most common bibliometric tools is the number of citations, which indicates the number of times an article has been cited by other articles. This method aims to identify the most impactful authors, institutions, countries, and journals within a defined subject area.

Studies using bibliometric analysis tools are common in the field of medical studies. For instance, Zou et al. [10] conducted the first study of OVs using data from
January 2000 to December 2018; whereas, this study will broaden the coverage up to two more years (data until March 2020). The previous study listed impactful journal, author, country and institutions. In addition to these, this study contributes by mapping the intellectual structure of the field through dynamic co-citation analysis. Unlike the present study, previous studies focused only on the type of cancer diseases [11], prevention of cancer [12], basic epidemiologic methods [13], and some ecologic studies $[14,15]$ focusing only on a specific country $[14,15]$, community, or neighbourhood. This study will help oncologists deepen their understanding of the ongoing application of oncolytic viruses in cancer patients worldwide.

\section{Methodology}

On March 2020, the literature search was conducted for relevant articles on the WoS database with the Boolean operator (("Oncolytic virus"” OR "Oncolytic virotherap") AND "Cancer")). The search resulted in 2529 articles, which were further refined to 1653 articles after excluding review studies (675), proceedings (28), meeting abstracts (80), editorial materials (66), book chapters (17), corrections (4), news items (4) and letters (2). Limiting only to the English language, the articles reduced to 1646 by excluding German (3), Chinse (2), and French (2). We manually reviewed the titles and abstracts of 1646 articles for relevance to our topic of interest and excluded 20 articles. Thus, the final sample for bibliometric analysis included 1626 articles published in 346 academic journals written by 7093 authors during the period of 2000-2020. Figure 1 presents the four steps filtering process. Once the sample was determined, we proceeded with citation and co-citation analysis using the Bibliometrix package [16] in the R-software. Only 32 articles were written by single authors, and on average, each article has 8.17 co-authors. In this study, we analyse previously published data and therefore did not need ethical approval.

\section{Bibliometric analysis results Publication trends}

The Bibliometric analysis method is useful in recognizing publication and citation trends in a field of study. As shown in Fig. 2a, we observed the number of publications grew gradually over the last 20 years. A few periods had steady growth such as 2002-2006, 2007-2012 and 2014-2017. Apart from a slight reduction in 2007, 2017 and 2018, in comparison to 2000, the number of publications have increased more than 18 folds in 2019. During this period two drugs, Talimogene laherparepvec (T-Vec) and Oncorine (H101), were approved by the US Food and Drug Administration (FDA) and the China FDA [17] and some OVs entered Phase III clinical trials. 


\section{Step 1: Keyword search in WoS: ("Oncolytic virus*" OR "Oncolytic virotherap*" AND "Cancer")}

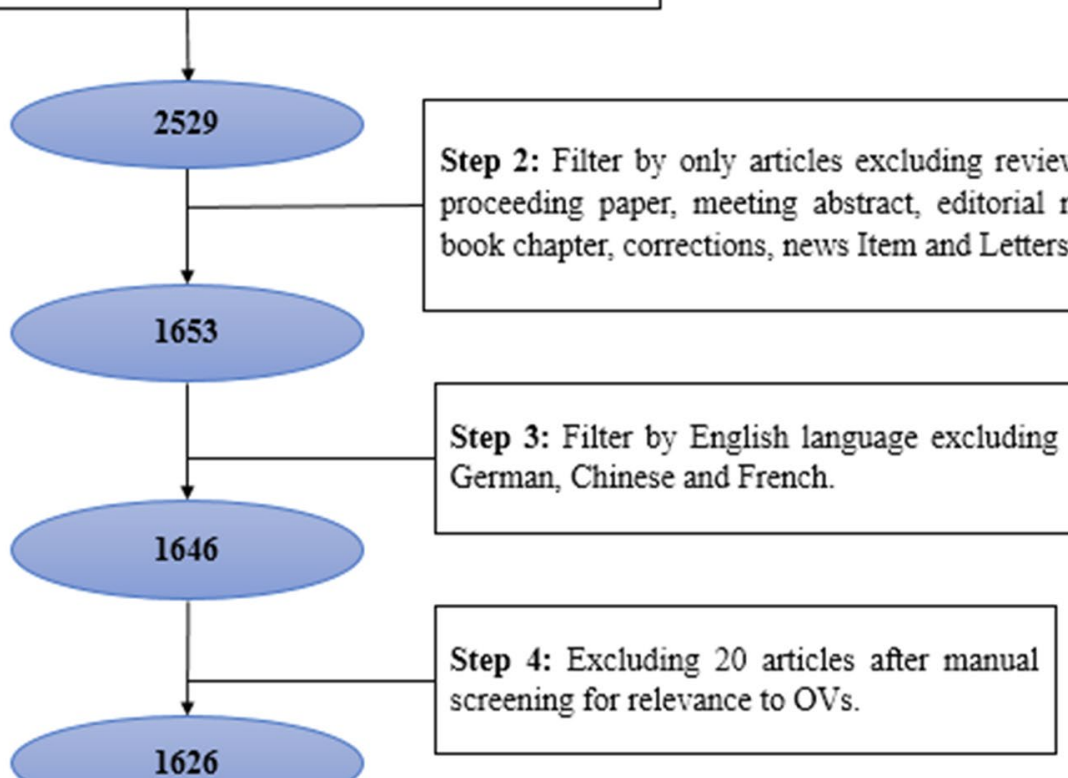

Fig. 1 Step-by-step literature search process

Meanwhile, Fig. 2b reports Total Local Citations (TLCs) and Total Global Citations (TGCs). TLCs indicate citations received by the sample of 1626 studies, and TGC indicates citations by all records indexed by WoS. The trends in both TLC and TGC are identical and show an overall lower citation in recent years. This is logical as it takes time for an article to make an impact and get citations after publication.

\section{Top journals}

The top academic journals, based on both the number of publications and the TLCs, are reported in Table 1. The top 20 academic journals which have published more than 15 articles on OVs topic include the journal Molecular Therapy $(\mathrm{N}=133)$, Cancer Gene Therapy $(\mathrm{N}=97)$ and Journal of Virology $(\mathrm{N}=75)$. The top 20 journals with the highest contribution to OVs research published 50.86\% of sample of 1626 studies. Molecular Therapy achieved the highest number of TLCs (1384), followed by Cancer Research (680) and Nature Medicine (418). The TGCs are noticeable as it indicates the potential of the publications beyond the OVs' research domain.

\section{Top institutions}

The top 20 contributing institutions in OVs research are presented in Table 2, including the number and percentage of publications from institutions, and their TLC and TGC. Mayo Clinic has published the most studies on OVs with 117 articles and covered 7.2\% of the whole literature on this basis, followed by the University of Ottawa $(\mathrm{N}=72,4.4 \%)$ and University of Helsinki $(\mathrm{N}=63$, $3.9 \%)$. In relation to the country profile, institutes in the United States of America (USA) has the majority of the top 20 institutions $(9 / 20)$, and the others are distributed between Canada (5/20), the United Kingdom (UK) $(3 / 20)$, Germany $(2 / 20)$, and Finland $(1 / 20)$.

\section{Most impactful authors}

Table 3 presents the top 20 authors in the domain of oncolytic virus research, where twenty authors have at least 10 articles in the field of OVs. Bell J.C has the highest number of articles (67) and total local citations (885), followed by Hemminki A. (51 documents and 278 TLC), Russell S.J (48 documents and 385 TLC), and Kanerva A. (39 documents and 25 TLC).

\section{Most impactful articles}

Table 4 presents the top 20 locally cited articles in OVs research during 2000-2020. The ranking is based on the total local citations per year (TLC/t). The table also presents total global citation per year (TGC/t), list of journals publishing the most impactful articles, and their cited reference. 
a

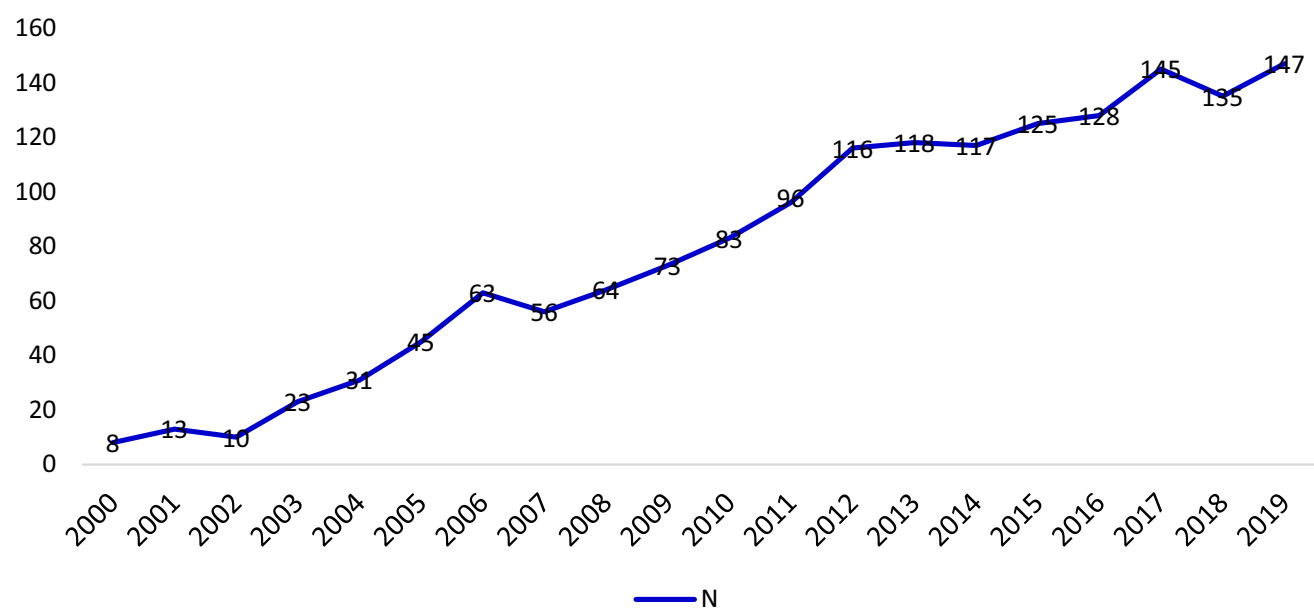

b

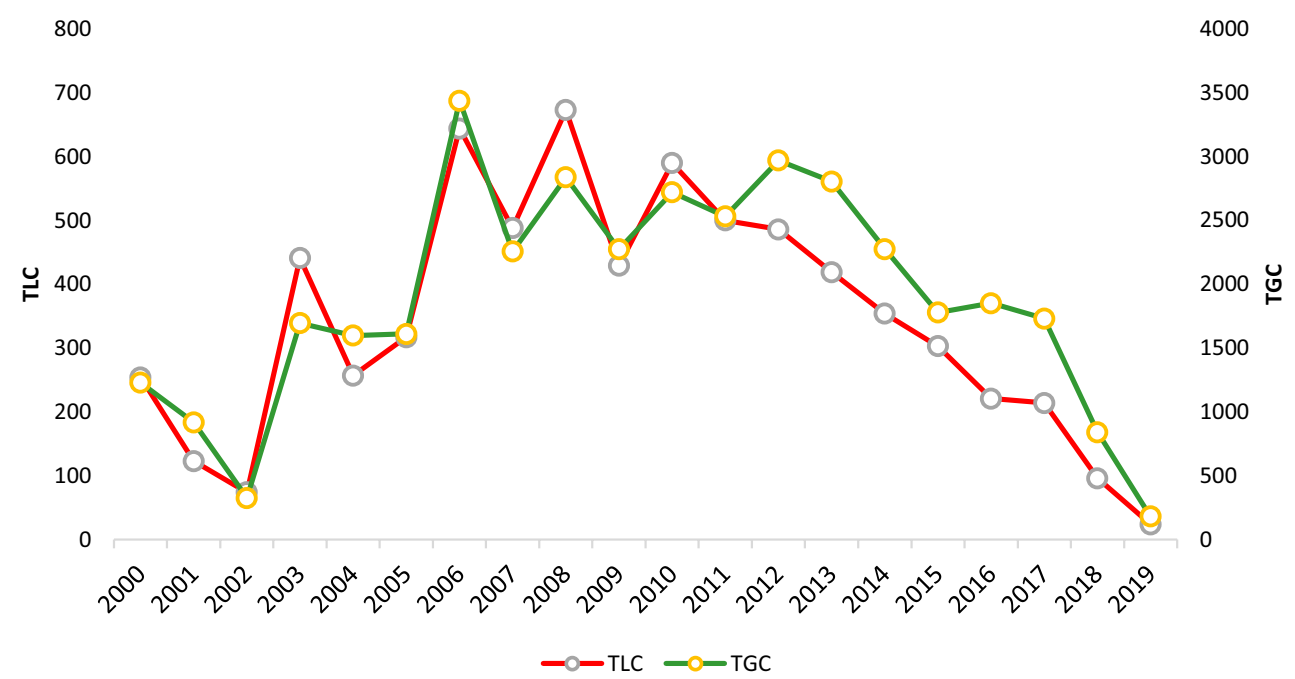

Fig. 2 Publication trends (excluding the year 2020). (a) Number of studies on OVs during 2000 and 2019, where N represents number of publications, and (b) Citations per year during 2000 and 2019, where TLC and TGC represent Total Local Citations and Total Global Citations, respectively

As shown in Table 4, the most highly cited article was published in the journal Cell in 2017 by Ribas et al. [18] and topped the lists of TLC/t (14.5) and TGC/t (78.25). The second article was published in the journal of Nature Medicine by Heo et al. [19], with $10.63 \mathrm{TLC} / \mathrm{t}$ and 47.63 TGC/t. Finally, Stojdl et al. [20], ranked third with 8.67 $\mathrm{TLC} / \mathrm{t}$ and $30.17 \mathrm{TGC} / \mathrm{t}$.

Amongst these top 20 articles, six were published in the journal of Molecular Therapy, three were published in Nature Medicine, two were published in the Proceedings of the National Academy of Sciences, and two were published in Clinical Cancer Research. On the other hand, as shown in Table 4 some journals including Cancer Cell, Journal of Clinical Oncology, Cancer Immunology Research, Journal of Clinical Investigation, Cell, Cancer Research, and Mayo Clinic proceedings, have published one of the top articles. Also, four articles had authors only from the USA; one article had just one country contribution authors such as Canada, Israel, and Finland. The remaining 13 articles had authors from more than two countries, meaning they resulted from international cooperation. 
Table 1 Top 20 journals in OV research

\begin{tabular}{|c|c|c|c|c|c|c|c|c|c|}
\hline Rank $^{a}$ & Journal & $\mathrm{N}$ & TLC & TGC & Rank $^{\text {b }}$ & Journal & $\mathbf{N}$ & TLC & TGC \\
\hline 1 & Molecular Therapy & 133 & 1384 & 5947 & 1 & Molecular Therapy & 133 & 1384 & 5947 \\
\hline 2 & Cancer Gene Therapy & 97 & 383 & 2091 & 2 & Cancer Research & 60 & 680 & 3287 \\
\hline 3 & Journal of Virology & 75 & 268 & 1293 & 3 & Nature Medicine & 10 & 418 & 1967 \\
\hline 4 & Cancer Research & 60 & 680 & 3287 & 4 & Clinical Cancer Research & 52 & 403 & 1806 \\
\hline 5 & Gene Therapy & 58 & 375 & 1788 & 5 & Cancer Gene Therapy & 97 & 383 & 2091 \\
\hline 6 & Molecular Therapy-Oncolytics & 56 & 15 & 292 & 6 & Gene Therapy & 58 & 375 & 1788 \\
\hline 7 & Clinical Cancer Research & 52 & 403 & 1806 & 7 & Journal of Virology & 75 & 268 & 1293 \\
\hline 8 & Human Gene Therapy & 43 & 197 & 935 & 8 & $\begin{array}{l}\text { Proceedings of The National Academy of } \\
\text { Sciences of The United States of America }\end{array}$ & 14 & 203 & 895 \\
\hline 9 & International Journal of Cancer & 42 & 196 & 898 & 9 & Human Gene Therapy & 43 & 197 & 935 \\
\hline 10 & Oncotarget & 39 & 92 & 515 & 10 & International Journal of Cancer & 42 & 196 & 898 \\
\hline 11 & Plos One & 37 & 0 & 695 & 11 & Cancer Cell & 6 & 194 & 966 \\
\hline 12 & Viruses-Basel & 20 & 4 & 101 & 12 & Oncotarget & 39 & 92 & 515 \\
\hline 13 & BMC Cancer & 18 & 0 & 345 & 13 & Current Opinion In Molecular Therapeutics & 15 & 83 & 391 \\
\hline 14 & Scientific Reports & 18 & 0 & 139 & 14 & Virology & 18 & 82 & 481 \\
\hline 15 & Virology & 18 & 82 & 481 & 15 & Journal of Theoretical Biology & 11 & 76 & 144 \\
\hline 16 & International Journal of Oncology & 16 & 42 & 224 & 16 & Journal of Clinical Investigation & 5 & 75 & 225 \\
\hline 17 & Oncoimmunology & 16 & 0 & 144 & 17 & Oncogene & 13 & 71 & 354 \\
\hline 18 & Current Opinion In Molecular Therapeutics & 15 & 83 & 391 & 18 & Molecular Cancer Therapeutics & 12 & 65 & 431 \\
\hline 19 & Journal of Gene Medicine & 15 & 48 & 299 & 19 & Cell & 1 & 58 & 313 \\
\hline 20 & Journal of Translational Medicine & 15 & 0 & 211 & 20 & Nature Biotechnology & 3 & 57 & 319 \\
\hline
\end{tabular}

TLC Total local citation, TGC total global citation

${ }^{\text {a }}$ Ranking based on number of publications

${ }^{\mathrm{b}}$ Ranking based on total local citations

\section{Most relevant countries}

Table 5 reports the 20 most relevant countries in terms of the number of publications. The USA (611 articles), China (197), and Canada (153) are the three most productive countries in OVs research. The majority of the articles published by the USA based researchers are single country publication (SCP) without having co-authors from other countries. Multiple Country Production (MCP) ratio indicates that authors based in Iran, Belgium, Austria, and France have collaboration worldwide.

\section{Intellectual structure of the research domain}

In this study, we use dynamic co-citation method for mapping the intellectual structure of the OVs research field. When two or more articles are cited together by other articles, they are called co-cited [37]. Co-cited articles are likely to share the same concepts as they were cited together by other studies. Hence, co-citation analysis allows us to map the intellectual structure of a research domain. Co-citation can also recognize knowledge networks and demonstrate their thematic progress over time, which we call dynamic co-citation. For dynamic co-citation mapping, we divide the sample of 1626 articles into three sub-samples based on their publication year grouping in an expanding horizon. For instance, in this study, the first group includes articles published during 2000-2005, the second group during 2000-2010 and the final group during 2000-2019. Hereafter, these sub-sampled articles were analysed using cocitation. Typically, co-citation analyses can be of three types depending on the unit of analysis (1) journal cocitation, (2) author co-citation, and (3) document cocitation. In this study, we conduct document co-citation network analyses. This approach helps to identify the growth and knowledge development of the OVs research over time.

Figure 3 presents the change in the intellectual structure of the research field over time. In Fig. 3a, b and c, the number of documents analysed were 130,469, and 1626, respectively. On the figures, each node represent an article. The size of the node presents the number of citations that the articles received. The line's thickness represents the strength of co-citations ties. The link and proximity between two items identify the co-citation relationship. The colour of the node indicates the associated cluster of an article. Each node was specified by the first author name and publication year of the article. Association strength normalisation algorithm has been used in the 
Table 2 Top 20 institutions in OV research

\begin{tabular}{|c|c|c|c|c|c|}
\hline Rank $^{a}$ & Institution & $\mathrm{N}$ & Percent (\%) & TLC & TGC \\
\hline 1 & Mayo Clinic & 117 & 7.2 & 929 & 3728 \\
\hline 2 & University of Ottawa & 72 & 4.4 & 847 & 3433 \\
\hline 3 & University of Helsinki & 63 & 3.9 & 308 & 1724 \\
\hline 4 & University of California San Diego & 53 & 3.3 & 196 & 1178 \\
\hline 5 & Ohio State University & 52 & 3.2 & 499 & 2650 \\
\hline 6 & University of Wurzburg & 52 & 3.2 & 165 & 873 \\
\hline 7 & Memorial Sloan Kettering Cancer Center & 46 & 2.8 & 271 & 1392 \\
\hline 8 & University of Pittsburgh & 45 & 2.8 & 335 & 1725 \\
\hline 9 & Institute of Cancer Research & 44 & 2.7 & 379 & 1574 \\
\hline 10 & McMaster University & 44 & 2.7 & 419 & 1725 \\
\hline 11 & Genelux Corporation & 42 & 2.6 & 140 & 722 \\
\hline 12 & German Cancer Research Center & 42 & 2.6 & 168 & 940 \\
\hline 13 & Harvard University & 38 & 2.3 & 267 & 1655 \\
\hline 14 & University of Calgary & 34 & 2.1 & 278 & 1141 \\
\hline 15 & Ottawa Hospital Research Institute & 33 & 2 & 222 & 1221 \\
\hline 16 & University of Surrey & 31 & 1.9 & 282 & 1182 \\
\hline 17 & Massachusetts General Hospital & 30 & 1.8 & 223 & 1255 \\
\hline 18 & Oncolytics Biotech Inc & 30 & 1.8 & 238 & 973 \\
\hline 19 & University of Florida & 28 & 1.7 & 107 & 564 \\
\hline 20 & University of Leeds & 28 & 1.7 & 341 & 1200 \\
\hline
\end{tabular}

$T L C$ Total local citation, TGC total global citation

${ }^{a}$ Ranking based on number of publications per university

Table 320 most impactful authors in OV research

\begin{tabular}{|c|c|c|c|c|c|c|c|c|}
\hline Rank $^{a}$ & Author & $N$ & TLC & $\mathrm{TLC} / \mathrm{t}$ & TGC & $\mathrm{TGC} / \mathrm{t}$ & TLCb & TLCe \\
\hline 1 & Bell JC & 67 & 885 & 77.93 & 3598 & 374.78 & 161 & 111 \\
\hline 2 & Russell SJ & 48 & 385 & 40.62 & 1684 & 176.11 & 101 & 57 \\
\hline 3 & Stojdl DF & 19 & 566 & 39.87 & 1970 & 159.31 & 64 & 70 \\
\hline 4 & Atkins $\mathrm{H}$ & 15 & 576 & 38.78 & 2041 & 143.11 & 61 & 68 \\
\hline 5 & Lichty BD & 23 & 416 & 36.62 & 1621 & 160.66 & 87 & 70 \\
\hline 6 & Vile $\mathrm{R}$ & 27 & 328 & 32.94 & 1225 & 131.04 & 109 & 51 \\
\hline 7 & Kirn DH & 14 & 347 & 32.74 & 1400 & 137.55 & 68 & 58 \\
\hline 8 & Melcher A & 30 & 328 & 31.9 & 1159 & 119.88 & 117 & 34 \\
\hline 9 & Kottke T & 23 & 313 & 29.36 & 1064 & 105.28 & 115 & 32 \\
\hline 10 & Thompson J & 22 & 313 & 29.36 & 1027 & 102.28 & 115 & 32 \\
\hline 11 & Selby P & 21 & 294 & 29.03 & 1112 & 114.99 & 88 & 49 \\
\hline 12 & Breitbach CJ & 10 & 253 & 28.2 & 1008 & 118.33 & 65 & 51 \\
\hline 13 & Hemminki A & 51 & 278 & 27.72 & 1515 & 156.7 & 87 & 34 \\
\hline 14 & Coffey M & 33 & 257 & 27.28 & 1101 & 126.75 & 65 & 42 \\
\hline 15 & Peng KW & 33 & 252 & 27.24 & 1216 & 130.69 & 68 & 36 \\
\hline 16 & Harrington $\mathrm{K}$ & 25 & 259 & 26.9 & 1024 & 111.58 & 84 & 33 \\
\hline 17 & Thorne SH & 27 & 280 & 25.53 & 1305 & 121.5 & 72 & 32 \\
\hline 18 & Diaz RM & 19 & 283 & 25.49 & 950 & 91.05 & 108 & 27 \\
\hline 19 & Kanerva A & 39 & 250 & 24.67 & 1313 & 132.12 & 76 & 30 \\
\hline 20 & Cerullo V & 32 & 189 & 24.67 & 942 & 125.51 & 62 & 26 \\
\hline
\end{tabular}

$T L C$ Total local citation, $T G C$ total global citation, $T L C b$ total local citation in the beginning, TLCe total local citation in the ending

${ }^{a}$ Ranking based on total local citations per year (TLC/t) 


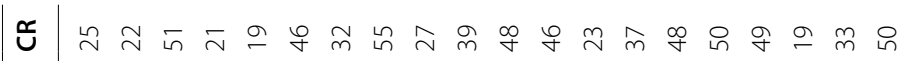

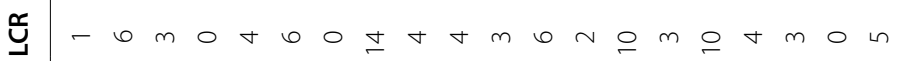

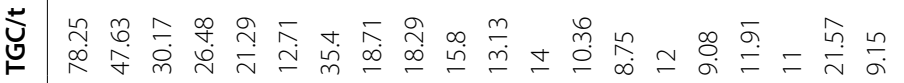

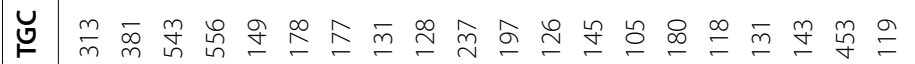

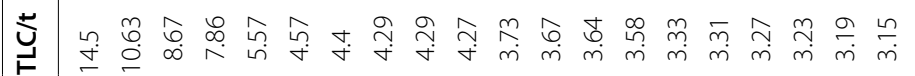

บํㅐ

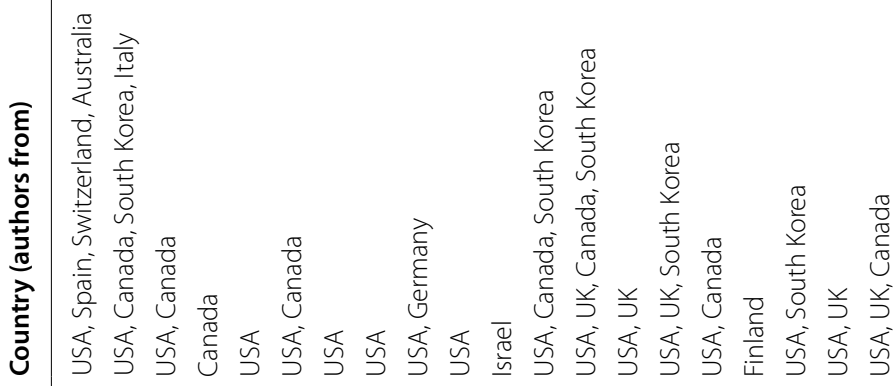

๘

高

产

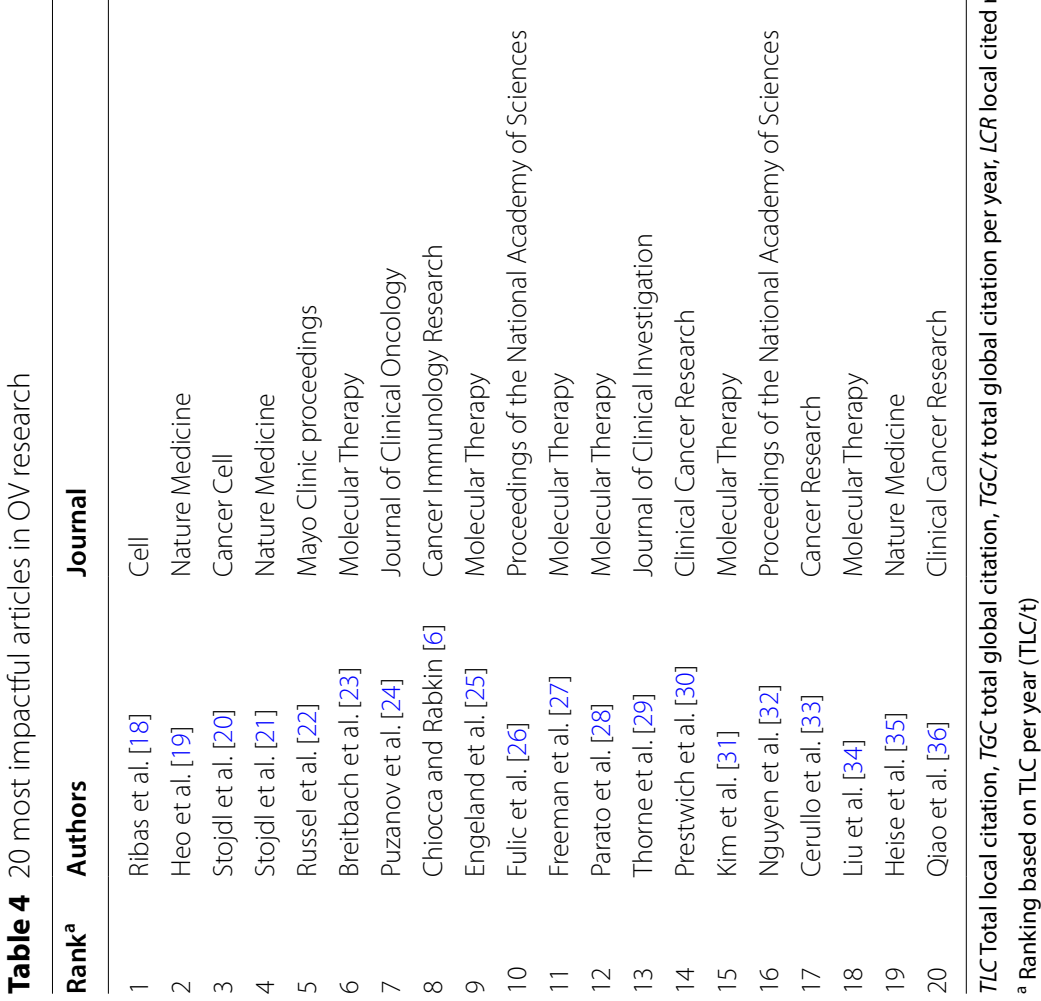


Table 5 Top 20 most relevant countries

\begin{tabular}{|c|c|c|c|c|c|}
\hline $\operatorname{Rank}^{a}$ & Country & Articles & SCP & MCP & MCP_Ratio \\
\hline 1 & USA & 611 & 442 & 169 & 0.28 \\
\hline 2 & China & 197 & 153 & 44 & 0.22 \\
\hline 3 & Canada & 153 & 104 & 49 & 0.32 \\
\hline 4 & Germany & 132 & 65 & 67 & 0.51 \\
\hline 5 & Japan & 109 & 84 & 25 & 0.23 \\
\hline 6 & United Kingdom & 93 & 39 & 54 & 0.58 \\
\hline 7 & Finland & 63 & 28 & 35 & 0.56 \\
\hline 8 & Spain & 41 & 29 & 12 & 0.29 \\
\hline 9 & Korea & 28 & 17 & 11 & 0.39 \\
\hline 10 & Italy & 26 & 13 & 13 & 0.50 \\
\hline 11 & France & 22 & 9 & 13 & 0.59 \\
\hline 12 & Netherlands & 18 & 9 & 9 & 0.50 \\
\hline 13 & Australia & 14 & 8 & 6 & 0.43 \\
\hline 14 & Iran & 12 & 4 & 8 & 0.67 \\
\hline 15 & Russia & 11 & 8 & 3 & 0.27 \\
\hline 16 & Sweden & 11 & 6 & 5 & 0.45 \\
\hline 17 & Austria & 10 & 4 & 6 & 0.60 \\
\hline 18 & Malaysia & 10 & 5 & 5 & 0.50 \\
\hline 19 & Belgium & 6 & 2 & 4 & 0.67 \\
\hline 20 & India & 6 & 5 & 1 & 0.17 \\
\hline
\end{tabular}

SCP Single country production, $M C P$ multiple country production

${ }^{a}$ Ranking based on number of articles

Bibliometrix package to identify the clusters. Documents that are more often cited together are more likely to have a similar research topic, documents within the same cluster have a solid co-citation relationship and tend to portion similar research focus or theoretical basis.

\section{OVs intellectual structure during 2000-2005}

As shown in Fig. 3a, the green cluster is one of the strongest among the three with 28 papers. In this cluster, Bischoff et al. [38], and Khuri et al. [39] had a stronger co-citation link. These articles report that several viruses have been engineered as oncolytic viruses. Bischoff et al. [38] reported adenovirus as one of the oncolytic viruses that is useful in treating human cervical carcinoma. They also reported the d11520 (Onyx-015) is the first genome modified Conditionally Replicative Adenoviruses based on human adenovirus type $2 / 5$ chimaera. Meanwhile, Khuri et al. [39] confirmed that the OXYN-15, the E1B$55 \mathrm{kDa}$ gene-deleted adenovirus, showed an anti-cancer effect in head and neck cancer.

On the other hand, the red cluster is significant in terms of total co-citation link strength. This cluster is organised by 15 documents. Markert et al. [40] have the greatest connection strength and a strong link with both Mineta et al. [41] and Martuza et al. [42]. A diversity of oncolytic viruses are being studied in clinical trials, including gene deletion mutants such as adenovirus, herpes simplex virus. HSV is one of the most important oncolytic viruses and is extensively studied as anti-tumour agents, both experimentally and clinically. In this context, Mineta et al. [41] reported that HSV-1 G207 is effective in treating brain tumour in BALB/c mice. For this purpose, G207 has deletions at $\gamma 34.5$ (RL1) loci and an insertion of the Escherichia coli lacZ gene. The lacZ gene insertion inactivates the ICP6 gene (UL39) that encodes the large subunit of ribonucleotide reductase. Also, the first phase clinical trials by Market et al. [40] reported that HSV-1 G207, which belongs to the second generation genetically engineered HSV-1 mutants, has been shown to be effective in the brain tumour therapy.

Finally, the blue cluster is the smallest among the three containing seven articles. Stojdl et al. [21] has reported for the first time that vesicular stomatitis virus (VSV), a replication-competent oncolytic virus, is sensitive to the interferon response and is tumour-specific, owing to the deficiency of antiviral interferon signalling pathways in tumour cells. It is recognized to preferentially infect and lyse a wide-range of cancerous cells in pre-clinical models and in patients. Also, Coffey et al. [43] reported that to infect a cell with human Reovirus (respiratory enteric orphan) the virus needs to have an activated Ras signalling pathway. Furthermore, they demonstrated that this virus may have applicability in the treatment of cancer such as glioblastoma.

\section{Extended OVs intellectual structure during 2000-2010}

In Fig. 3b, we examine the co-citation network of the second sub-sample studies published between 2000 and 2010. In comparison to Fig. 3a, the current figure has changes in cluster structures, although some remain stable. The blue cluster from Fig. 3a breaks down to two clusters in Fig. 3b-the red cluster with Stojdl et al. [21] at the centre and the green cluster with Coffey et al. [43] at the centre. The figure shows that the intellectual structure of the oncolytic viruses has extended and changed over time.

The green cluster contains nine documents about Reovirus, Newcastle disease virus, and Herpes simplex virus. All of these documents confirmed that Reovirus has potent activity against cancers such as colon cancer, breast cancer, ovarian cancer, and malignant gliomas in vitro, in vivo, and ex vivo. Hirasawa et al. [44] revealed that the use of systemic delivery of Reovirus agent concerning immune-suppressive drugs effectively prolongs animal survival. Pecora et al. [45] reported that in the first phase trial of PV701, a replication-competent strain of Newcastle disease virus can provide a novel and potentially important therapy for patients with solid tumours after intravenous administration. 

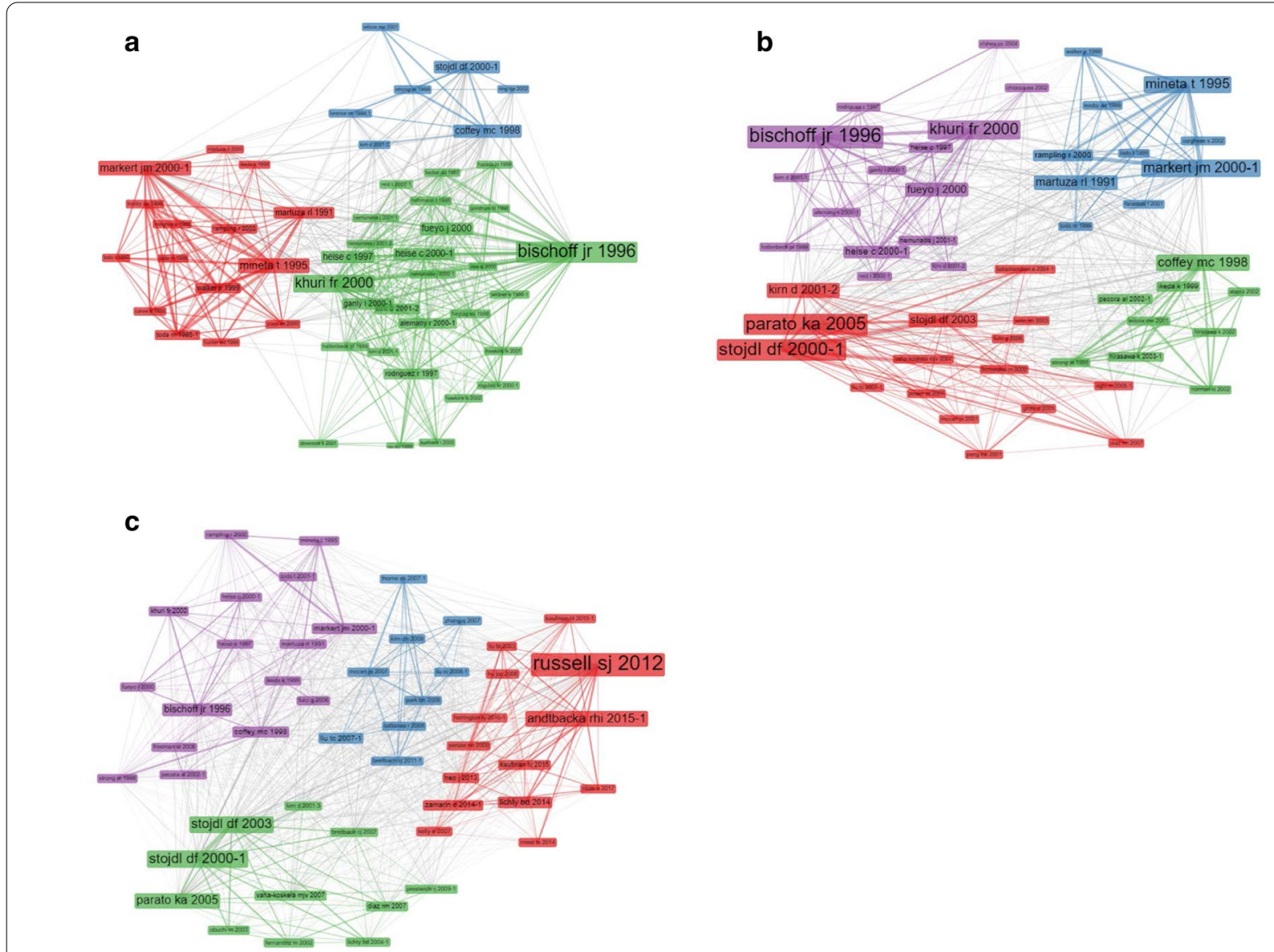

Fig. 3 Dynamic co-citation mapping (2000-2019). (a) Co-citation 2000-2005, (b) Co-citation 2000-2010, (c) Co-citation 2000-2019

The blue cluster (identical to the red cluster in Fig. 3a) has ten documents and almost all of the articles in this cluster focus on the oncolytic herpes simplex virus. Markert et al. [40], Mineta et al. [41], Martuza et al. [42], and Rampling et al. [46] have more document cocitations when compared to other studies. These studies confirmed the use of herpes simplex virus (ICP 34.5 null mutant 1716) in patients.

The purple cluster (identical to the green cluster in Fig. 3a) contains 15 documents, and it represents influential papers on adenovirus during 2000-2010. In this cluster, Khuri et al. [39], and Bischoff et al. [33] have more co-citations compared to the other authors. Meanwhile, we observed that several researchers worked on adenovirus in different clinical trial phases such as Reid et al. [47] and Khuri et al. [39] on Phase I, and Nemunaitis et al. [48] Phase II. Moreover, in the current cluster, we found that four review articles, Kirn [49], Kirn et al. [50], Alemany et al. [51], and Chiocca [52] have noticeable documents co-citations. Kirn [49] surveyed all the clinical trials about d11520 (Onyx-015), which is the first genetically engineered agent to test on humans with an E1B-55 gene deletion. On the other hand, Alemany et al. [51] revealed types of conditionally replicative adenoviruses (CRAds) used as oncolytic agents till now.

The red cluster represents influential studies on OVs during 2000-2010, and consists of 16 documents. The majority of documents focus on applying vesicular stomatitis virus in the case of in vitro and in vivo studies on tumour cell lines model. We have also found that other OVs such as HSV, Measles, Adenovirus, and Vaccinia are potent anti-cancer agents. From these articles, four review articles by Kirn et al. [50], Parato et al. [53], Aghi and Martuza [54], and Liu et al. [55] explained the type of clinical trials of OVs. Vähä-Koskela et al. [56] investigated some of the recent additions to the panel of OVs including yaba-like disease virus, avian adenovirus, myxoma virus, bovine herpesvirus 4 (BHV-4), foamy virus, echovirus type 1, saimiri virus, sendai virus, feline panleukopenia virus, and the non-human coronaviruses. Also, Wein et al. [57] reported using preclinical and clinical 
data to validate the mathematical model of replicationcompetent adenovirus for cancer treatment.

\section{New developments during 2000-2019}

As shown in Fig. 3a, documents in all three clusters (Red, Blue, and Green) are about different oncolytic viruses in the tumour cells model. Since the development in genetic engineering at the start of the 1990s, use of engineered oncolytic viruses for cancer therapy have increased [42]. Figure $3 \mathrm{~b}$ represents the change in the intellectual structure of the oncolytic viruses during this period. Finally, Fig. 3c focuses on the new developments in oncolytic viruses during 2000-2019.

As shown in Fig. 3c, the purple cluster is one of the strongest among others, with 16 documents. In this cluster, the majority of the documents repeat from Fig. 3a and b, except Toda et al. [58] and Freeman et al. [27]. Freeman et al. [27] revealed that the NDV-HUJ strain of Newcastle disease virus had shown good tolerability in phase I/II clinical trial for the treatment of glioblastoma multiforme (GBM), as well as other cancers. Also, the authors confirmed that lentogenic NDV strains should also be surveyed in patients with lower-grade gliomas. Todo et al. [58] reported the use of soluble B7-1 in the context of oncolytic HSV for immune gene therapy and is clinically suitable in in-situ cancer vaccination.

The red cluster has 14 documents and concentrates on HSV, NDV, and vaccinia virus. Six of the papers in this cluster explored the HSV. In this cluster, six review articles-Kelly and Russell [59], Harrington et al. [60], Russell et al. [61], Lichty et al. [62], Miest and Cattaneo [63], and Kaufman et al. [64] had the most document cocitation. Russell et al. [61] and Andtbacka et al. [65] were the most co-cited studies of this cluster. Russell et al. [61] reported that oncolytic virotherapy is a novel therapeutic modality that uses replication-competent viruses against cancers. Additionally, Andtbacka et al. [65] revealed that T-VEC is the first oncolytic immunotherapy to display therapeutic profit against melanoma in phase III clinical trial. Also, it can represent a potential advance treatment for patients with injectable metastatic melanoma. However, in the current cluster, all of the documents are new document in co-citation, and these documents do not include in Fig. 3a or b. During this period (2000-2019) some development includes-the possibility of a singleshot virotherapy treatment, recognition of new drugs to speed up intratumoral virus diffusion, augmentation of the immunotherapeutic action of OVs, and clinical confirmation of a critical threshold of virus in the blood for vascular delivery and virus replication within the tumour [61].

The green cluster contains 11 documents among which some repeats from Fig. 3b except Obuchi et al. [66],
Lichty et al. [67], Breitbach et al. [23], and Prestwich et al. [30]. Out of 11 documents, four are review studies. These studies surveyed three phases of the clinical trial of oncolytic viruses in different tumour cell models. Lichty et al. [67] described VSV as a therapeutic oncolytic virus. On the other hand, Prestwich et al. [30] discussed Reovirus as it generates adaptive antitumor immunity in vitro and in vivo studies. Additionally, Breitbach et al. [23] revealed that unappreciated and unanticipated interaction between VSV and vaccinia virus, and inflammatory response in the tumour.

The last cluster is the blue one with nine articles out of which five are review studies. This cluster consists of new studies except McCart et al. [68]. Liu and Kirn [69], Liu and Kirn [70], and Cttaneoet al. [71] reviewed some phases of the clinical trial of oncolytic viruses in different tumour cell models. Thorne [72] discussed oncolytic viruses, eukaryotic cells, and attenuated bacteria and the mechanisms to deliver them systemically to tumours, including in case of micro metastases. In this cluster, other studies by McCart et al. [68], Zhang et al. [73], and Park et al. [74] were focused on the oncolytic Poxviridae family. Moreover, for the first time, Breitbach et al. [75] reported that VSV is able to infect tumour neovasculature in vivo, but normal tissue vascular endothelium is resistant to the virus infection.

\section{Discussion}

This study discusses a diversity of OVs that has potential for types of anti-cancer therapy. Since its development, genetically engineered OVs are studied as a suitable alternative to non-engineered viruses (wild-type). As cancer therapy field has changed, OVs have an improved therapeutic index. Although the accumulated data has impressive recent development in cancer therapy using oncolytic viruses, it is prevented at many levels and may require assistance to reach full efficacy. Several studies also reported that oncolytic virotherapy could be utilised for antitumor treatment through different combination strategies such as chemotherapy, radiotherapy, systemic immunotherapies, etc. [7, 56, 76, 77]. This combination has resulted in enhance apoptosis induction and showed significant result in a wide range of tumour models. Most popular drugs that fall into the classes are cyclophosphamide (CPA) doxorubicin, camptothecin (CPT), 5-fluorouracil (5-FU), ganciclovir (GCV), cisplatin, mitomycin C (MMC), paclitaxel, carboplatin, rapamycin, rituximab, and docetaxel [78-80]. Additionally, Vähä-Koskela et al. [56] reported OVs such as adenovirus in combination with chemotherapy, have been confirmed as a standard therapy to treat refractory nasopharyngeal cancer in China. 
During the last decade, the fast extension of global OVs research resulted in benefits to the population. Son et al. [81] revealed the combination of OVs with various therapies leads to improved infection efficiency and increased antitumor effects. They suggested that the cytopathic effects of measles and mumps viruses' combination (MM) can improve the antitumor activity and tumour cell killing in vitro and in vivo. For further research, the study proposed explaining the ability of the antitumor reactions of oncolytic viruses and combination. Moreover, the recent study by Al-Shammari et al. [82] confirmed that combination therapy of oncolytic Newcastle disease virus and ribes rhizomes extract enhanced the anticancer activity. Interestingly, the study proposes the combination of OVs with herbal therapy which may result in novel anticancer therapy. Several studies measured the treating advantage of radionuclide therapy in combination with oncolytic viruses and external beam radiotherapy. The results showed that OVs combined with expressing the sodium iodide symporter (NIS) in various tumour models could restrict tumour growth and increase survival [83-86].

As shown in Table 4, North America, including the USA and Canada, has a strong effect on the oncolytic virus research, while European institutions, including the UK, Germany, and Finland, also play a prominent role. Demir et al. [87] revealed that countries with significant economic potency such as United States, Japan, the United Kingdom, Canada, Australia, and China could be the most impactful in terms of the number of publications which is in line with our results.

The USA, being the leading high-tech power upon the offset of the Second World War, leads many global research arenas. Such an issue was also considered in our study in terms of the numbers of articles, institutions, and scientists, showing that USA scientists have contributed greatest influence on virotherapy advancement. The science and technology operational impact policy, the rich financial support was driven from public foundations and private enterprises, and the implementation of new or better devices developed in the USA serves as the potential bases for the USA's most considerable contribution [88].

\section{Limitation}

The first publication regarding OVs' role in clinical or preclinical studies, was published in 1912 [59]. The database used in this study, WoS, only list publications from 1980 which left behind previous studies. But as a novel therapy, most development in OVs has occurred recently; therefore, recent studies would give a better overview of the current state of the study domain. This study did not cover scientific literature from Scopus and PubMed, and only journals with an impact factor (IF) are indexed in the WoS database. While this exclude studies published in the journals without an IF, eventually results a review of only high-quality studies. Moreover, studies confirmed the use of only the WoS for the bibliometric study exerts more reliable results than other databases of peerreviewed scientific literature such as Scopus and PubMed [87].

\section{Conclusion}

This study provides a holistic review of the present body of literature focusing on oncolytic viruses as one of the potential therapies in cancer treatment. This review maps the intellectual structure development of OV research during 2000 to 2020 using dynamic co-citation analysis. From the content analysis of the most co-cited studies, adenovirus, herpes simplex virus, Reovirus, and Newcastle disease virus have shown potent activity on the treatment of several cancer types. Based on citation analysis, the developed countries were the most productive in publications on OVs. Conducting multinational research studies would help other countries to enter into the research domain and get the possible benefit. The findings of this bibliometric review provide beneficial knowledge for clinicians, especially for oncologists and researchers, for exploring OVs considering development trends.

\section{Abbreviations \\ OVs: Oncolytic viruses; GM: Genetically modified; NDV: Newcastle disease virus; SVV: Seneca valley virus; VSV: Vesicular stomatitis virus; HSV: Herpes sim- plex virus; WoS: Web of Science; T-Vec: Talimogene laherparepvec; Pexa-Vec: Pexastimogene devacirepvec.}

\section{Acknowledgements}

The authors are thankful to the Vice-Chancellor of Research and Technology of Hamadan University of Medical Sciences, Hamadan, Iran, and the Biotechnology Development Council of the Islamic Republic of Iran for support (961102).

\section{Authors' contribution}

ASMN writing original draft, revised and edited the manuscript; TN data curtain, revised and edited of draft; ZHM formal analysis, revised and editing of draft; MYA supervision, writing and revised manuscript; AG revised and edited of draft. All authors read and approved the final manuscript.

\section{Funding}

The study did not receive any external funding.

\section{Availability of data and material}

We have attached the bibliography data analyzed in this study in zip format for consideration.

\section{Declaration}

Ethics approval and consent to participate

Our study titled "A bibliometric review of Oncolytic virus research as a novel approach for cancer therapy" authored by Amir Sasan Mozafari Nejad, Tehjeeb 
Noor, Ziaul Haque Munim, Amir Ghaemi and Mohammad Yousef Alikhani submitted to the journal Virology Journal is a literature review study which analyze bibliography data of published articles from the Web of Science database. The study did not collect any primary data including data of human species. Therefore, ethics approval is not applicable for this study.

\section{Consent for publication}

As our study does not include any individual person's data in any form (including individual details, images or videos), consent to publication is not applicable.

\section{Competing interests}

The authors declare no financial and non-financial competing interests.

\section{Author details}

${ }^{1}$ Research Center for Molecular Medicine, Hamadan University of Medical Sciences, Hamadan, Iran. ${ }^{2}$ Faculty of Medicine, University of Bergen, Horten, Norway. ${ }^{3}$ Faculty of Technology, Natural and Maritime Sciences, University of South-Eastern Norway, Horten, Norway. ${ }^{4}$ Department of Microbiology, Faculty of Medicine, Hamadan University of Medical Sciences, Hamadan, Iran. ${ }^{5}$ Department of Influenza and Other Respiratory Viruses, Pasteur Institute of Iran, Tehran, Iran.

Received: 7 November 2020 Accepted: 3 May 2021

Published online: 12 May 2021

\section{References}

1. Bray F, Ferlay J, Soerjomataram I, Siegel RL, Torre LA, Jemal A. Global cancer statistics 2018: GLOBOCAN estimates of incidence and mortality worldwide for 36 cancers in 185 countries. CA Cancer J Clin. 2018;68:394-424.

2. Richters A, Aben KK, Kiemeney LA. The global burden of urinary bladder cancer: an update. World J Urol. 2020;38:1895-904.

3. Krzyszczyk P, Acevedo A, Davidoff EJ, Timmins LM, Marrero-Berrios I, Patel $M$, et al. The growing role of precision and personalized medicine for cancer treatment. Technology. 2018;6:79-100.

4. Russell L, Peng K-W. The emerging role of oncolytic virus therapy against cancer. Chin Clin Oncol. 2018;7:16.

5. Kaufman HL, Atkins MB, Subedi P, Wu J, Chambers J, Mattingly TJ, et al. The promise of immuno-oncology: implications for defining the value of cancer treatment. J Immunother Cancer. 2019;7:129.

6. Chiocca EA, Rabkin SD. Oncolytic viruses and their application to cancer immunotherapy. Cancer Immunol Res. 2014;2:295-300.

7. Zheng M, Huang J, Tong A, Yang H. Oncolytic viruses for cancer therapy: barriers and recent advances. Mol Ther Oncolytics. 2019;15:234-47.

8. Nejad ASM, Fotouhi F, Mehrbod P, Keshavarz M, Alikhani MY, Ghaemi A. Oncolytic effects of Hitchner B1 strain of newcastle disease virus against cervical cancer cell proliferation is mediated by the increased expression of cytochrome C, autophagy and apoptotic pathways. Microb Pathog. 2020;147:104438.

9. Keshavarz M, Nejad ASM, Esghaei M, Bokharaei-Salim F, Dianat-Moghadam $\mathrm{H}$, Keyvani $\mathrm{H}$, et al. Oncolytic Newcastle disease virus reduces growth of cervical cancer cell by inducing apoptosis. Saudi J Biol Sci. 2020;27:47-52.

10. Zou Y, Luo Y, Zhang J, Xia N, Tan G, Huang C. Bibliometric analysis of oncolytic virus research, 2000 to 2018. Medicine. 2019;98:e16817.

11. He L, Fang H, Chen C, Wu Y, Wang Y, Ge H, et al. Metastatic castrationresistant prostate cancer: Academic insights and perspectives through bibliometric analysis. Medicine. 2020;99:19760.

12. Fitzmaurice C, Allen C, Barber RM, Barregard L, Bhutta ZA, Brenner $H_{\text {, }}$ et al. Global, regional, and national cancer incidence, mortality, years of life lost, years lived with disability, and disability-adjusted life-years for 32 cancer groups, 1990 to 2015: a systematic analysis for the global burden of disease study. JAMA Oncol. 2017:3:524-48.
13. Wark PA, Peto J. Cancer epidemiology. In: Quah SR, editor. International encyclopedia of public health. 2nd ed. Oxford: Academic Press; 2017. p. 339-46.

14. Grant WB. An ecological study of cancer mortality rates in the United States with respect to solar ultraviolet-B doses, smoking, alcohol consumption, and urban/rural residence. Dermatoendocrinol. 2010;2:68-76.

15. Fazzo L, Santis MD, Mitis F, Benedetti M, Martuzzi M, Comba P, et al. Ecological studies of cancer incidence in an area interested by dumping waste sites in Campania (Italy). Ann Ist Super Sanita. 2011;47:181-91.

16. Aria M, Cuccurullo C. bibliometrix: An R-tool for comprehensive science mapping analysis. J Informet. 2017;11:959-75.

17. Wei D, Xu J, Liu X-Y, Chen Z-N, Bian H. Fighting cancer with viruses: oncoIytic virus therapy in China. Hum Gene Ther. 2018;29:151-9.

18. Ribas A, Dummer R, Puzanov I, VanderWalde A, Andtbacka RH, Michielin $\mathrm{O}$, et al. Oncolytic virotherapy promotes intratumoral T cell infiltration and improves anti-PD-1 immunotherapy. Cell. 2017;170:1109-19.

19. Heo J, Reid T, Ruo L, Breitbach CJ, Rose S, Bloomston M, et al. Randomized dose-finding clinical trial of oncolytic immunotherapeutic vaccinia JX-594 in liver cancer. Nat Med. 2013;19:329.

20. Stojdl DF, Lichty BD, Paterson JM, Power AT, Knowles S, Marius R, et al. VSV strains with defects in their ability to shutdown innate immunity are potent systemic anti-cancer agents. Cancer Cell. 2003;4:263-75.

21. Stojdl DF, Lichty B, Knowles S, Marius R, Atkins H, Sonenberg N, et al. Exploiting tumor-specific defects in the interferon pathway with a previously unknown oncolytic virus. Nat Med. 2000;6:821-5

22. Russell SJ, Federspiel MJ, Peng K-W, Tong C, Dingli D, Morice WG, et al. Remission of disseminated cancer after systemic oncolytic virotherapy. Mayo Clin Proc. 2014;89:926-33.

23. Breitbach CJ, Paterson JM, Lemay CG, Falls TJ, McGuire A, Parato KA, et al. Targeted inflammation during oncolytic virus therapy severely compromises tumor blood flow. Mol Ther. 2007:15:1686-93.

24. Puzanov I, Milhem MM, Minor D, Hamid O, Li A, Chen L, et al. Talimogene laherparepvec in combination with ipilimumab in previously untreated, unresectable stage IIIB-IV melanoma. J Clin Oncol. 2016;34:2619-26.

25. Engeland CE, Grossardt C, Veinalde R, Bossow S, Lutz D, Kaufmann JK, et al. CTLA-4 and PD-L1 checkpoint blockade enhances oncolytic measles virus therapy. Mol Ther. 2014;22:1949-59.

26. Fulci G, Breymann L, Gianni D, Kurozomi K, Rhee SS, Yu J, et al. Cyclophosphamide enhances glioma virotherapy by inhibiting innate immune responses. Proc Natl Acad Sci. 2006;103:12873-8.

27. Freeman Al, Zakay-Rones Z, Gomori JM, Linetsky E, Rasooly L, Greenbaum $E$, et al. Phase I/II trial of intravenous NDV-HUJ oncolytic virus in recurrent glioblastoma multiforme. Mol Ther. 2006;13:221-8.

28. Parato KA, Breitbach CJ, Le Boeuf F, Wang J, Storbeck C, Ilkow C, et al. The oncolytic poxvirus JX-594 selectively replicates in and destroys cancer cells driven by genetic pathways commonly activated in cancers. Mol Ther. 2012;20:749-58

29. Thorne SH, Hwang T-HH, O'Gorman WE, Bartlett DL, Sei S, Kanji F, et al. Rational strain selection and engineering creates a broad-spectrum, systemically effective oncolytic poxvirus, JX-963. J Clin Invest. 2007:117:3350-8

30. Prestwich RJ, Ilett EJ, Errington F, Diaz RM, Steele LP, Kottke T, et al. Immune-mediated antitumor activity of reovirus is required for therapy and is independent of direct viral oncolysis and replication. Clin Cancer Res. 2009:15:4374-81.

31. Kim J, Oh J, Park B, Lee D, Kim J, Park H, et al. Systemic armed oncolytic and immunologic therapy for cancer with JX-594, a targeted poxvirus expressing GM-CSF. Mol Ther. 2006:14:361-70.

32. Nguyên TL-A, Abdelbary H, Arguello M, Breitbach C, Leveille S, Diallo J-S, et al. Chemical targeting of the innate antiviral response by histone deacetylase inhibitors renders refractory cancers sensitive to viral oncolysis. Proc Natl Acad Sci. 2008;105:14981-6.

33. Cerullo V, Pesonen S, Diaconu I, Escutenaire S, Arstila PT, Ugolini M, et al. Oncolytic adenovirus coding for granulocyte macrophage colony-stimulating factor induces antitumoral immunity in cancer patients. Can Res. 2010:70:4297-309. 
34. Liu T-C, Hwang T, Park B-H, Bell J, Kirn DH. The targeted oncolytic poxvirus JX-594 demonstrates antitumoral, antivascular, and anti-HBV activities in patients with hepatocellular carcinoma. Mol Ther. 2008;16:1637-42.

35. Heise C, Hermiston T, Johnson L, Brooks G, Sampson-Johannes A, Williams A, et al. An adenovirus E1A mutant that demonstrates potent and selective systemic anti-tumoral efficacy. Nat Med. 2000;6:1134-9.

36. Qiao J, Wang H, Kottke T, White C, Twigger K, Diaz RM, et al. Cyclophosphamide facilitates antitumor efficacy against subcutaneous tumors following intravenous delivery of reovirus. Clin Cancer Res. 2008;14:259-69.

37. Small H. Co-citation in the scientific literature: a new measure of the relationship between two documents. J Am Soc Inf Sci. 1973:24:265-9.

38. Bischoff JR, Kirn DH, Williams A, Heise C, Horn S, Muna M, et al. An adenovirus mutant that replicates selectively in p53-deficient human tumor cells. Science. 1996;274:373-6.

39. Khuri FR, Nemunaitis J, Ganly I, Arseneau J, Tannock IF, Romel L, et al. A controlled trial of intratumoral ONYX-015, a selectively-replicating adenovirus, in combination with cisplatin and 5-fluorouracil in patients with recurrent head and neck cancer. Nat Med. 2000;6:879-85.

40. Markert J, Medlock M, Rabkin S, Gillespie G, Todo T, Hunter W, et al. Conditionally replicating herpes simplex virus mutant, G207 for the treatment of malignant glioma: results of a phase I trial. Gene Ther. 2000;7:867-74.

41. Mineta T, Rabkin SD, Yazaki T, Hunter WD, Martuza RL. Attenuated multimutated herpes simplex virus-1 for the treatment of malignant gliomas. Nat Med. 1995:1:938-43.

42. Martuza RL, Malick A, Markert JM, Ruffner KL, Coen DM. Experimental therapy of human glioma by means of a genetically engineered virus mutant. Science. 1991;252:854-6.

43. Coffey MC, Strong JE, Forsyth PA, Lee PW. Reovirus therapy of tumors with activated Ras pathway. Science. 1998:282:1332-4.

44. Hirasawa K, Nishikawa SG, Norman KL, Coffey MC, Thompson BG, Yoon C-S, et al. Systemic reovirus therapy of metastatic cancer in immune-competent mice. Can Res. 2003;63:348-53.

45. Pecora AL, Rizvi N, Cohen Gl, Meropol NJ, Sterman D, Marshall JL, et al. Phase I trial of intravenous administration of PV701, an oncolytic virus, in patients with advanced solid cancers. J Clin Oncol. 2002;20:2251-66.

46. Rampling R, Cruickshank G, Papanastassiou V, Nicoll J, Hadley D, Brennan $D A$, et al. Toxicity evaluation of replication-competent herpes simplex virus (ICP 34.5 null mutant 1716) in patients with recurrent malignant glioma. Gene Ther. 2000;7:859-66.

47. Reid T, Warren R, Kirn D. Intravascular adenoviral agents in cancer patients: lessons from clinical trials. Cancer Gene Ther. 2002;9:979-86.

48. Nemunaitis J, Cunningham C, Buchanan A, Blackburn A, Edelman G, Maples $\mathrm{PA}$, et al. Intravenous infusion of a replication-selective adenovirus (ONYX$015)$ in cancer patients: safety, feasibility and biological activity. Gene Ther. 2001:8:746-59.

49. Kirn D. Clinical research results with dl1520 (Onyx-015), a replication-selective adenovirus for the treatment of cancer: what have we learned? Gene Ther. 2001;8:89-98.

50. Kirn D, Martuza RL, Zwiebel J. Replication-selective virotherapy for cancer: biological principles, risk management and future directions. Nat Med. 2001;7:781-7.

51. Alemany R, Balagué C, Curiel DT. Replicative adenoviruses for cancer therapy. Nat Biotechnol. 2000;18:723-7.

52. Chiocca EA. Oncolytic viruses. Nat Rev Cancer. 2002;2:938-50.

53. Parato KA, Senger D, Forsyth PA, Bell JC. Recent progress in the battle between oncolytic viruses and tumours. Nat Rev Cancer. 2005;5:965.

54. Aghi M, Martuza RL. Oncolytic viral therapies-the clinical experience. Oncogene. 2005;24:7802-16.

55. Liu T-C, Galanis E, Kirn D. Clinical trial results with oncolytic virotherapy: a century of promise, a decade of progress. Nat Clin Pract Oncol. 2007:4:101-17.

56. Vähä-Koskela MJ, Heikkilä JE, Hinkkanen AE. Oncolytic viruses in cancer therapy. Cancer Lett. 2007;254:178-216.

57. Wein LM, Wu JT, Kirn DH. Validation and analysis of a mathematical model of a replication-competent oncolytic virus for cancer treatment: implications for virus design and delivery. Can Res. 2003;63:1317-24.
58. Todo T, Martuza RL, Dallman MJ, Rabkin SD. In situ expression of soluble B7-1 in the context of oncolytic herpes simplex virus induces potent antitumor immunity. Can Res. 2001;61:153-61.

59. Kelly E, Russell SJ. History of oncolytic viruses: genesis to genetic engineering. Mol Ther. 2007;15:651-9.

60. Harrington K, Vile RG, Melcher A, Chester J, Pandha H. Clinical trials with oncolytic reovirus: moving beyond phase I into combinations with standard therapeutics. Cytokine Growth Factor Rev. 2010;21:91-8.

61. Russell SJ, Peng K-W, Bell JC. Oncolytic virotherapy. Nat Biotechnol. 2012;30:658.

62. Lichty BD, Breitbach CJ, Stojdl DF, Bell JC. Going viral with cancer immunotherapy. Nat Rev Cancer. 2014;14:559-67.

63. Miest TS, Cattaneo R. New viruses for cancer therapy: meeting clinical needs. Nat Rev Microbiol. 2014;12:23-34.

64. Kaufman HL, Kohlhapp FJ, Zloza A. Oncolytic viruses: a new class of immunotherapy drugs. Nat Rev Drug Discov. 2015;14:642-62.

65. Andtbacka R, Kaufman HL, Collichio F, Amatruda T, Senzer N, Chesney J, et al Talimogene laherparepvec improves durable response rate in patients with advanced melanoma. J clin Oncol. 2015;33:2780-8.

66. Obuchi M, Fernandez M, Barber GN. Development of recombinant vesicular stomatitis viruses that exploit defects in host defense to augment specific oncolytic activity. J Virol. 2003;77:8843-56.

67. Lichty BD, Power AT, Stojdl DF, Bell JC. Vesicular stomatitis virus: re-inventing the bullet. Trends Mol Med. 2004:10:210-6.

68. McCart JA, Ward JM, Lee J, Hu Y, Alexander HR, Libutti SK, et al. Systemic cancer therapy with a tumor-selective vaccinia virus mutant lacking thymidine kinase and vaccinia growth factor genes. Can Res. 2001;61:8751-7.

69. Liu T-C, Kirn D. Systemic efficacy with oncolytic virus therapeutics: clinical proof-of-concept and future directions. Can Res. 2007;67:429-32.

70. Liu T-C, Kirn D. Gene therapy progress and prospects cancer: oncolytic viruses. Gene Ther. 2008;15:877-84.

71. Cattaneo R, Miest T, Shashkova EV, Barry MA. Reprogrammed viruses as cancer therapeutics: targeted, armed and shielded. Nat Rev Microbiol. 2008;6:529-40.

72. Thorne SH. Strategies to achieve systemic delivery of therapeutic cells and microbes to tumors. Expert Opin Biol Ther. 2007;7:41-51.

73. Zhang Q, Yong AY, Wang E, Chen N, Danner RL, Munson PJ, et al. Eradication of solid human breast tumors in nude mice with an intravenously injected light-emitting oncolytic vaccinia virus. Can Res. 2007;67:10038-46.

74. Park B-H, Hwang T, Liu T-C, Sze DY, Kim J-S, Kwon H-C, et al. Use of a targeted oncolytic poxvirus, JX-594, in patients with refractory primary or metastatic liver cancer: a phase I trial. Lancet Oncol. 2008;9:533-42.

75. Breitbach CJ, De Silva NS, Falls TJ, Aladl U, Evgin L, Paterson J, et al. Targeting tumor vasculature with an oncolytic virus. Mol Ther. 2011;19:886-94.

76. Leber MF, Neault S, Jirovec E, Barkley R, Said A, Bell JC, et al. Engineering and combining oncolytic measles virus for cancer therapy. Cytokine Growth Factor Rev. 2020:56:39-48

77. Zhang B, Cheng P. Improving antitumor efficacy via combinatorial regimens of oncolytic virotherapy. Mol Cancer. 2020;19:1-16.

78. Karapanagiotou EM, Roulstone V, Twigger K, Ball M, Tanay M, Nutting C, et al. Phase I/II trial of carboplatin and paclitaxel chemotherapy in combination with intravenous oncolytic reovirus in patients with advanced malignancies. Clin Cancer Res. 2012:18:2080-9.

79. Lun XQ, Jang J-H, Tang N, Deng H, Head R, Bell JC, et al. Efficacy of systemically administered oncolytic vaccinia virotherapy for malignant gliomas is enhanced by combination therapy with rapamycin or cyclophosphamide Clin Cancer Res. 2009:15:2777-88.

80. Lee J-C, Shin DW, Park H, Kim J, Youn Y, Kim JH, et al. Tolerability and safety of EUS-injected adenovirus-mediated double-suicide gene therapy with chemotherapy in locally advanced pancreatic cancer: a phase 1 trial. Gastrointest Endosc. 2020;92:1044-52.

81. Son HA, Zhang L, Cuong BK, Van Tong H, Cuong LD, Hang NT, et al. Combination of vaccine-strain measles and mumps viruses enhances oncolytic activity against human solid malignancies. Cancer Invest. 2018;36:106-17.

82. Al-Shammari AM, Jalill RDA, Hussein MF. Combined therapy of oncolytic Newcastle disease virus and rhizomes extract of Rheum ribes enhances cancer virotherapy in vitro and in vivo. Mol Biol Rep. 2020;47:1691-702. 
83. Mansfield D, Kyula J, Rosenfelder N, Chao-Chu J, Kramer-Marek G, Khan A, et al. Oncolytic vaccinia virus as a vector for therapeutic sodium iodide symporter gene therapy in prostate cancer. Gene Ther. 2016;23:357-68.

84. Miller A, Russell SJ. The use of the NIS reporter gene for optimizing oncolytic virotherapy. Expert Opin Biol Ther. 2016;16:15-32.

85. Wu ZJ, Tang FR, Ma Z-W, Peng X-C, Xiang Y, Zhang Y, et al. Oncolytic viruses for tumor precision imaging and radiotherapy. Hum Gene Ther 2018;29:204-22.

86. Opyrchal M, Allen C, lankov I, Aderca I, Schroeder M, Sarkaria J, et al. Effective radiovirotherapy for malignant gliomas by using oncolytic measles virus strains encoding the sodium iodide symporter (MV-NIS). Hum Gene Ther. 2012:23:419-27.
87. Demir E, Akmeşe Ö, Erbay H, Taylan-Özkan A, Mumcuoğlu K. Bibliometric analysis of publications on house dust mites during 1980-2018. Allergol Immunopathol. 2020;48:374-83.

88. He L, Fang H, Wang X, Wang Y, Ge H, Li C, et al. The 100 most-cited articles in urological surgery: a bibliometric analysis. Int J Surg. 2020;75:74-9.

\section{Publisher's Note}

Springer Nature remains neutral with regard to jurisdictional claims in published maps and institutional affiliations.
Ready to submit your research? Choose BMC and benefit from:

- fast, convenient online submission

- thorough peer review by experienced researchers in your field

- rapid publication on acceptance

- support for research data, including large and complex data types

- gold Open Access which fosters wider collaboration and increased citations

- maximum visibility for your research: over $100 \mathrm{M}$ website views per year

At BMC, research is always in progress.

Learn more biomedcentral.com/submissions 